University at Buffalo School of Law

Digital Commons @ University at Buffalo School of Law

Journal Articles

Faculty Scholarship

Winter 1-1-1979

\title{
Comments on the History of Plea Bargaining
}

Lynn M. Mather

University at Buffalo School of Law

Follow this and additional works at: https://digitalcommons.law.buffalo.edu/journal_articles

Part of the Criminal Law Commons, and the Legal History Commons

\section{Recommended Citation}

Lynn M. Mather, Comments on the History of Plea Bargaining, 13 Law \& Soc'y Rev. 281 (1979).

Available at: https://digitalcommons.law.buffalo.edu/journal_articles/846

(C) 1979 Law and Society Association. Reproduced with permission.

\section{IN COPYRIGHT}

This Article is brought to you for free and open access by the Faculty Scholarship at Digital Commons @ University at Buffalo School of Law. It has been accepted for inclusion in Journal Articles by an authorized administrator of Digital Commons @ University at Buffalo School of Law. For more information, please contact lawscholar@buffalo.edu. 


\title{
COMMENTS ON THE HISTORY OF PLEA BARGAINING
}

\author{
LYNN M. MATHER
}

Both Alschuler and Friedman provide valuable data on the history of plea bargaining, showing the emergence of the guilty plea in the mid-nineteenth century and a large increase in plea bargaining after 1900 . If this material is to aid our understanding of contemporary plea bargaining, we must explore the conditions that gave rise to the practice. Other papers have discussed important changes in the criminal justice process; my comments will be directed to two changes in the substance of the criminal law during this period. I want to suggest how changing ideas of punishment and sentencing, as well as expansion of the criminal law, also contributed to the rise of plea bargaining.

Criminal law in the early nineteenth century was based on the penology of Beccaria, Bentham, and other utilitarian philosophers. Because the primary goal of punishment was deterrence, sentences were to be determined according to the offense rather than the offender. By the end of the century a "new penology" had emerged, based on a philosophy of individualized sanctions that sought to reform (later to rehabilitate) the offender. In an effort to make the punishment fit the individual a variety of new procedures were introduced, such as "indeterminate" sentences, prison classification systems, juvenile courts, different penalties for youthful offenders, and presentence investigations (Vasoli, 1965:405). Parole and probation also developed during this period; the latter evolved from the common law practice of suspending sentence into a more formal program involving probation officers who made written reports to the court, and supervised the convict's compliance with the restrictive conditions of probation. For example, California's probation law, Penal Code $\S 1203$, although enacted in 1872, was substantially rewritten in 1903 to create probation in its more modern form. Between 1903 and 1923 the statute was amended eight times to refine probation as an alternative in sentencing.

Not everyone accepted these penal reforms, however, and public reaction in the 1920 s called for greater severity in sentencing. Roscoe Pound noted unhappily that before these penal innovations could fully be implemented and "experts" 
trained to use them, "the public, dissatisfied with the palpable inefficiency of our criminal justice in urban centers, began to charge the ill-workings of the whole system upon these innovations" (1930:197). It was not accidental that most of the criticism of plea bargaining came, as Alschuler suggests, "from the hawks of the criminal process rather than the doves" (supra:232). Plea bargaining facilitated the individualization of punishment. It was a way for judges and prosecutors to reach a sentence that, in their view, would be more appropriate for the needs of the individual offender.

There was a tension between such "forward-looking reforms" as probation and a criminal code that set penalties according to the offense involved (Moley, 1929:188). Although Moley was generally critical of "justice by compromise," he also achnowledged that "real justice can sometimes be achieved best by compromising a case out of court" (1929:186). In the conclusion of his book, Moley argued that:

The whole task of dealing with crime is not one for which the traditional processes of law are suitable. The slow but irresistible development of scientific thought concerning the criminal compels a greater individualization of treatment than a general law will permit .... The practice of accepting pleas to a lesser offense is a clumsy and undesirable device, it is true, but it is in part made necessary by the need for individualizing-making the punishment fit the criminal rather than the crime. To a greater extent we may expect to find the common sense of officials breaking the bounds of legal devices which have outlived the philosophy which created them. [1929:236; emphasis mine]

An important question, of course, is the extent to which plea compromises actually did reflect a concern for substantive justice in the individual case rather than the pressures of administrative expediency or simply political influence. ${ }^{1}$ Notwithstanding the data marshalled by both Friedman and Alschuler to show that those who pled guilty received more lenient sentences than those convicted at trial, substantive sentencing concerns may still have been quite relevant to the disposition process. $^{2}$ Clearly judges and prosecutors had a stake in encouraging pleas of guilty. But their administrative interests may also have been consistent with what they saw as progressive, reform-oriented sentencing. The ideas of the "new penology" became available at the turn of the century to rationalize and justify the discretionary acts of court officials.

A second change, the tremendous growth of the criminal

1 This remains an important question for plea bargaining research. It is addressed effectively by Utz (1978) in her comparison of plea bargaining in San Diego and Oakland.

2 The sentence disparity between guilty plea and trial convictions might be far less striking if attention were paid to the facts of the offense and the background of the offender. For further discussion, see Mather (1979:39). 
law, also contributed to the rise of plea bargaining in the late nineteenth and early twentieth century. Alschuler discusses this factor primarily in terms of the administrative problems facing the courts as they tried to cope with the increased caseloads. But not only were the cases appearing in greater numbers, they were also of a distinctly different type. The substance of the criminal law had changed so that, "many acts which were formerly regulated by social or business customs . . . have now been denounced by appropriate criminal legislation and turned over to the enforcement officers" (Miller, 1927:17; see supra:234 n.18). This new criminal legislation did not always have the full weight of the community behind it, however, and juries would sometimes refuse to convict. Frequent dismissals and plea bargaining by prosecutors reflected, in part, public ambivalence about criminalizing such conduct.

It is important to ask which cases were being compromised and which settled by full trial. Friedman's data might answer this question if disposition were analyzed by offense. In 1927, Miller suggested such a line of inquiry and presented an informal survey of district attorneys throughout California. According to these prosecutors, the offenses most frequently compromised included issuing bad checks, forgery, auto theft, larceny, nonsupport, statutory rape, liquor law violations, and motor vehicle offenses. ${ }^{3}$ For some of these crimes, the prosecutors pointed to the difficulty of obtaining convictions, but in others they noted that civil remedies had been secured: defendants made restitution for bad checks, returned stolen cars, provided for their families, or married the underage girl (see Miller, 1927:13-17). As the District Attorney of Sutter County, California explained, "there are many cases where technical violations of the law have been committed, but where the facts show no serious infraction of the law" (Miller, 1927:16). This is precisely the kind of comment prosecutors make today when justifying a plea reduction on the ground that the case "does not warrant felony treatment." There is also a similarity in the types of cases most frequently settled by plea bargains then and now, if drug offenses are substituted for liquor offenses (see Mather, 1974:213).

The problem for criminal law administrators is that they are not only supposed to keep order and settle disputes. They

3 Miller described these offenses in the text of his article and in numerous footnotes reporting letters from the various prosecutors (1927:13-17). Moley noted that in Chicago in 1926, pleas to lesser offenses were accepted most often in property crimes and least frequently in personal crimes such as homocide and rape (1929:179). 
must also, as Thurman Arnold pointed out, dramatize the moral values of the community; hence plea compromises are seen as unacceptable because they tarnish the ideal of "Law Enforcement" (1962:152-62). Perhaps it is the different symbolism evoked by the criminal law that explains why negotiated settlements are criticized there while they are praised and encouraged in civil law. With the expansion of the criminal law to include what were formerly civil trespasses, and with new penal ideas that deemphasized deterrence and punishment, it was harder to justify the sharp distinction between criminal and civil procedure (Miller, 1927:25-30). Miller suggested that society consider distinguishing a class of criminal cases (perhaps called "public torts") in which compromises would be permitted, although such negotiation would not be allowed in other crimes (1927:29-30). ${ }^{4}$

These comments on penal changes and the growth of the law must, of course, acknowledge the importance of the changes mentioned in the other papers. I would particularly underscore the rise of professional police and prosecutors as an explanation for the decline of adversary trials. Today, when cases undergo extensive pretrial screening before they reach court, there are relatively few genuine disputes over guilt or innocence left to be resolved by juries. In felony cases, at least, the theme has emerged clearly from recent research: the vast majority of defendants in court are guilty of something, and the prosecution has the evidence to prove it.

Finally, the distinction drawn by Friedman between implicit and explicit plea bargains is an important one. But it is necessary to exercise caution in labeling a plea as one or the other on the basis of court records alone. For example, an initial, on-the-nose plea of guilty might well reflect an implicit plea bargain as Friedman suggests. But it could just as easily result from an explicit sentence promise made prior to entry of the plea. In fact, such a plea could even reflect explicit charge reduction, as in Newman's description of plea bargaining in Kansas (1966:91-92). There, he noted, defendants negotiated with prosecutors after the arrest but before the filing of the information; charges were reduced and defendants then pled guilty to the new charge. However, since charges were reduced prior to the arraignment, the official record would present "an

4 In some ways this is similar to what is accomplished today by prosecutorial policies that prohibit plea bargaining in certain very serious offenses. 
illusion of on-the-nose pleas" (1966:91).5 It may be misleading to infer an historical movement from implicit to explicit plea bargaining on the basis of increases in changed pleas and reduced charges, without observational data about the actual nature of the negotiation process.

\section{REFERENCES}

ARNOLD, Thurman W. (1962) The Symbols of Government. New York: Harcourt, Brace \& World.

MATHER, Lynn M. (1974) "Some Determinants of the Method of Case Disposition: Decision-Making by Public Defenders in Los Angeles," 8 Law \& Society Review 187.

- (1979) Plea Bargaining or Trial? The Process of Criminal Case Disposition. Lexington, Mass.: Lexington Books.

MILLER, Justin (1927) "The Compromise of Criminal Cases," 1 Southern Califormia Law Review 1.

MOLEY, Raymond (1929) Politics and Criminal Prosecution. New York: Minton, Balch.

NEWMAN, Donald J. (1966) Conviction: The Determination of Guilt or Innocence without Trial. Boston: Little, Brown.

POUND, Roscoe (1930) Criminal Justice in America. New York: Henry Holt.

UTZ, Pamela (1978) Settling the Facts: Discretion and Negotiation in Criminal Court. Lexington, Mass.: Lexington Books.

VASOLI, Robert H. (1965) "Growth and Consequences of Judicial Discretion in Sentencing," 40 Notre Dame Lawyer 404.

5 On the other hand, a change of plea could reflect implicit or explicit bargaining. For example, virtually all pleas of guilty in the Central District of Los Angeles Superior Court in 1970 were changed from initial not guilty pleas because of a Master Calendar system that restricted the opportunity for plea negotiation at arraignment. When defendants did plead guilty later, in their assigned trial courtroom, some pleas reflected implicit, and others explicit, plea bargaining (see Mather, 1979:53, 65-72). 